\title{
Impairment of lipoglycoprotein metabolism in rat liver cells induced by 1,2-dichloroethane
}

Damiano Cottalasso, Giovanni Barisione, Luigi Fontana, Cinzia Domenicotti, Maria Adelaide Pronzato, Giorgio Nanni

\begin{abstract}
Background-1,2-Dichloroethane (DCE) is a volatile liquid readily absorbed through dermal, digestive, or inhalatory routes. After inhalation or oral administration to rats, death occurs within a narrow range of concentrations ( $s i x$ hour $\mathbf{L C}_{50}=5100 \mathrm{mg} / \mathrm{m}^{3}$ ). Exposure to single high doses of DCE resulted in adverse effects on the central nervous system, liver, kidneys, adrenals, and lungs. The liver showed fatty changes and hepatocellular necrosis with haemorrhage. These injuries are probably related to changes in several cell functions and constituents. Therefore, it was decided to investigate whether DCE was capable of impairing the secretion of hepatocellular lipoglycoproteins acting both at the level of the Golgi apparatus and endoplasmic reticulum.
\end{abstract}

Methods-Isolated hepatocytes of Wistar rats were prelabelled with two precursors of lipoglycoproteins ${ }^{3} \mathrm{H}-\mathrm{Na}$-palmitate and ${ }^{14} \mathrm{C}$-glucosamine, and then exposed to concentrations of DCE from mean (SD) $4.4(0.03)$ to $6.5(0.02) \mathrm{mM}$ for different durations ranging from five to $60 \mathrm{~min}$ utes. To measure lipid and sugar bound radioactivity, a preliminary separation of cell homogenate, cytosol, total microsomes, Golgi apparatus, and lipoglycoproteins secreted into cell suspension medium was carried out.

Results-After five minutes of exposure, DCE did not induce obvious changes in cell viability or lactic dehydrogenase leakage, but a significant $(p<0.01)$ depletion of reduced glutathione content was seen $\left(40 \cdot 10 \quad(4 \cdot 3) \quad n M / 10^{6}\right.$ cells $)$. Furthermore, the cells poisoned by DCE started to show noticeable accumulation of ${ }^{3} \mathrm{H}$-Na-palmitate in the Golgi apparatus after five minutes $\left(5103\right.$ (223) $\mathrm{dpm} / 10^{6}$ cells) and in the microsomes after 15 minutes (85 470 (7190) $\mathrm{dpm} / 10^{6}$ cells). There was a simultaneous significant increase in ${ }^{14} \mathrm{C}$-glucosamine content in the Golgi apparatus (690 (55) $\mathrm{dpm} / 10^{6}$ cells) and the microsomes (15 975 (2035) $\mathrm{dpm} / 10^{6}$ cells). The specific radioactivity of lipid and sugar moieties incorporated in secreted lipoglycoproteins was already significantly reduced after only five minutes of exposure (480 (57) $\mathrm{dpm} / 10^{6}$ cells for lipids, and 315 (45) $\mathrm{dpm} / 10^{6}$ cells for sugars).

Conclusions-Overall, DCE, like other haloalkanes, produces a block of secretion of hepatocellular lipoglycoproteins as early as five minutes after poisoning. The simultaneous percentage increases into Golgi apparatus and microsomes of lipid and sugar bound radioactivity suggest that lipid retention at the sites of processing of lipoglycoproteins would probably play an important part in the early stages of cellular accumulation of fat after exposure to DCE.

(Occup Environ Med 1994;51:281-285)

1,2-Dichloroethane (DCE) is a colourless, flammable, and volatile liquid extensively used as an intermediate in the synthesis of halogenated hydrocarbons, particularly vinyl chloride. ${ }^{1}$ Other minor uses are as an industrial solvent and a fumigant. ${ }^{2}$ Occasional and prolonged human exposure to this xenobiotic compound is increasing worldwide and occurs within and near production facilities. Data concerning levels of exposure are, however, scarce. ${ }^{34}$

Several experimental and clinical investigations have shown that, after inhalation and oral ingestion, the liver seems to be the major target organ. ${ }^{5}$ Exposure of rats to single high doses of DCE resulted in adverse effects on the central nervous system, liver, kidneys, adrenals, and lungs (six hour $\left.\mathrm{LC}_{50}=5100 \mathrm{mg} / \mathrm{m}^{3}\right){ }^{6}$ When given to rodents, DCE is quickly absorbed and biotransformed, mainly by the liver, into urinary metabolites through two known pathways. One of these includes a P-450 mediated microsomal hydroxylation to 2-chloroacetaldehyde and 2-chloroethanol, ${ }^{7}$ and the other a conjugation with the reduced form of glutathione. ${ }^{8}$ This conjugation is widely influenced by the centrolobular $\mathrm{O}_{2}$ mean partial pressure $\left(\mathrm{PO}_{2}\right) .{ }^{9}$ Thus it is reasonable to suspect that the liver zonal changes induced by DCE, consisting of either fat storage or necrosis, ${ }^{56}$ may depend on critical depletion of intracellular reduced glutathione content. ${ }^{10}$

Several investigators have shown that a block of synthesis, processing, and secretion into the bloodstream of hepatic lipoglycoproteins, and particularly of the very low density fraction, may represent the crucial mechanism underlying toxic fatty liver. Different steps of the secretory pathway are probably involved in the expression of such damage, which occurs very soon after poisoning. ${ }^{11-13}$

Both in vitro studies with isolated rat liver 
cells and experiments carried out with whole animals, provided direct evidence that ethanol ${ }^{14}$ and carbon tetrachloride $\left(\mathrm{CCl}_{4}\right)^{15}$ might impair the intracellular traffic of lipoglycoprotein micelles, and also indicated a probable derangement of the functions of the Golgi apparatus. ${ }^{16}$ Furthermore, the amounts in the Golgi apparatus of the dolichols, a family of long chain polyisoprenoid molecules that play a key part in the glycosylation processes, decrease early compared with amounts in total microsomes, in particular on the secretory side $\left(F_{1}\right)$ of the Golgi apparatus. ${ }^{17} 18$

The purpose of this study was to investigate the pathogenesis of impairment of the Golgi apparatus that actually takes place within five minutes of exposure to DCE in the intact rat hepatocyte model. To assess the part played by the block of the secretory pathway of hepatic lipoglycoprotein in fat accumulation, the changes induced by DCE in the cell uptake and release of two prelabelled precursors of lipoglycoproteins, ${ }^{3} \mathrm{H}-\mathrm{Na}$-palmitate and ${ }^{14} \mathrm{C}$-glucosamine, were evaluated.

\section{Materials and methods}

ANIMALS, DIET, AND REAGENTS

Adult male rats of the Wistar strain (obtained from S Morini sas, S Polo d'Enza, Reggio Emilia, Italy), weighing $250-300 \mathrm{~g}$, were used. They were maintained under a 12 hour light/12 hour dark cycle with controlled feeding (a standard semisynthetic antioxidant free diet from Italiana Mangimi, Settimo Milanese, Milano, Italy), and free access to water for one week before use. The DCE and reduced glutathione were obtained from $\mathrm{E}$ Merck, Darmstadt, Germany. Trypan blue and collagenase type I were obtained from Sigma Chemical Co, St Louis, Missouri, USA; lactic dehydrogenase was evaluated with kits from Poli Diagnostici, Industria Chimica Spa, Milano, Italy. The $9-10-{ }^{3} \mathrm{H}-$ palmitic acid (specific activity $60 \mathrm{mCi} / \mathrm{mM}$ ) and $\mathrm{D}-{ }^{14} \mathrm{C}$-glucosamine (specific activity $57 \mathrm{mCi} / \mathrm{mM}$ ) were from the Radiochemical Centre, Amersham, Bucks, UK; and liquid scintillation fluid (Pico-Fluor TM40) from Packard Chemicals, Groningen, The Netherlands. All other chemicals were at least of reagent grade and purchased from $\mathrm{BDH}$ Italia, Milano, Italy or from E Merck, Darmstadt, Germany.

\section{PREPARATION OF ISOLATED HEPATOCYTES}

Rat liver cells were isolated by the Berry and Friend method, ${ }^{19}$ successively modified. ${ }^{20}$ The buffers and medium used during hepatocyte isolation and incubation procedures were prepared according to Poli et al. ${ }^{15}$ The liver of rats, previously anaesthetised with sodium pentobarbitone $(50 \mathrm{mg} / \mathrm{kg}$ of body weight), were first perfused through the portal vein with $100 \mathrm{ml}$ of warm $\left(37^{\circ} \mathrm{C}\right)$ saline buffer $A$. This contained $0.143 \mathrm{M} \mathrm{NaCl}, 7 \mathrm{mM} \mathrm{KCl}$, $10 \mathrm{mM}$ HEPES NaOH buffer pH 7*4. Then, the livers were perfused with $100 \mathrm{ml}$ of warm $\left(37^{\circ} \mathrm{C}\right)$ saline buffer $\mathrm{B}(0 \cdot 1 \mathrm{M} \mathrm{NaCl}, 7 \mathrm{mM}$
$\mathrm{KCl}, 5 \mathrm{mM} \mathrm{CaCl}, 50 \mathrm{mM}$ HEPES NaOH buffer $\mathrm{pH} 7 \cdot 6$ ) containing $0.050 \%$ collagenase type I. After this, they were removed and dispersed into $200 \mathrm{ml}$ of medium $C(60 \mathrm{ml}$ $\mathrm{NaCl}, 40 \mathrm{mM} \mathrm{KCl}, 50 \mathrm{mM}$ HEPES $\mathrm{NaOH}$ buffer pH 7.4, $1 \mathrm{mM} \mathrm{CaCl}, 2 \mathrm{mM} \mathrm{MgSO}_{4}$, $1 \mathrm{mM} \mathrm{Na} \mathrm{HPO}_{4}, 5 \mathrm{mM}$ glucose, $0.58 \mathrm{mM}$ amino acid mixture). The hepatocyte suspension, filtered through a $200 \mu \mathrm{m}$ mesh, was centrifuged at $400 \mathrm{~g}$ for four minutes, and the pellet was resuspended in medium $C$. After counting with a haemocytometer, the cells were diluted with the same medium to $5-7 \times 10^{6} \mathrm{cells} / \mathrm{ml}$. Cell yields ranged from $200-300 \times 10^{6}$ cells per liver. Hepatocyte viability was routinely assessed by the trypan blue exclusion test ${ }^{20}$ and by colorimetric measurement of release of lactate dehydrogenase in a suspension medium. ${ }^{15}$ The extracellular enzyme activity was expressed as a percentage of total (intracellular plus extracellular) enzyme activity determined after cell destruction with $0.5 \%$ Triton X100. Hepatocyte preparations with viability ranging from $83 \%$ to $86 \%$ were used..$^{21} 22$

\section{PRELABELLING OF HEPATOCYTES}

The 9-10-3 $\mathrm{H}$-palmitic acid was converted to 9-10- ${ }^{3} \mathrm{H}-\mathrm{Na}$-palmitate with $\mathrm{NaOH}$. Successively, the liver cells in medium $\mathrm{C}$ were prelabelled with $1.51 \mu \mathrm{Ci} / \mathrm{ml}$ of $5 \%$ bovine albuminbound $9-10-{ }^{3} \mathrm{H}-\mathrm{Na}$-palmitate for 45 minutes and with $0.16 \mu \mathrm{Ci} / \mathrm{ml}$ of ${ }^{14} \mathrm{C}$-glucosamine for 15 minutes. After this time, the cell suspension was diluted $1: 10$ with medium $C$ and centrifuged at $400 \mathrm{~g}$ for four minutes. Both the ${ }^{3} \mathrm{H}$-Na-palmitate and ${ }^{14} \mathrm{C}$-glucosamine labelled hepatocytes were suspended in medium $\mathrm{C}$ to give $5-7 \times 10^{6} \mathrm{cells} / \mathrm{ml}$.

\section{POISONING OF ISOLATED HEPATOCYTES WITH DCE}

Three $\mathrm{ml}$ aliquots of cell suspension were placed into the main compartment of $50 \mathrm{ml}$ flasks fitted with a centre well, and closed with a screw cap. Then DCE was added to the centre well and allowed to diffuse in the closed system. The flasks were incubated for five to 60 minutes at $37^{\circ} \mathrm{C}$ in a Dubnoff bath. Control cells were incubated in the same way, but without DCE. By adding $5.5 \mu \mathrm{l}$ ( $1 \mu \mathrm{l}=1.2569 \mathrm{mg}$ ) of DCE, the actual concentration of this haloalkane was determined on a Varian 3500 capillary gas cromatograph, equipped with electron detector. Columns were fused silica $30 \mathrm{~m} \times 0.25 \mathrm{~mm}$ internal diameter DBWAX from $J$ and $W$ Scientific (Folsom, CA, USA).

\section{REDUCED GLUTATHONE ASSAY}

Intracellular reduced glutathione content was measured by a fluorimetric method, ${ }^{23}$ and is expressed as $\mathrm{nM} / 10^{6}$ cells.

\section{PREPARATION OF SECRETED}

LIPOGLYCOPROTEIN FRACTION

The secreted lipoglycoprotein fraction was obtained by adding one part of $2 \%$ sodium phosphotungstate (pH 7.6) in $1 \mathrm{M} \mathrm{MgCl}_{2}$ to nine parts of cell incubation medium $\mathrm{C}$. The 
Table 1 Time course of DCE concentration in cell suspension medium (determined after adding $5.5 \mu \mathrm{l}$ ( $1 \mu l=1 \cdot 2569 \mathrm{mg}) \mathrm{DCE}$ in the centre well of flasks)

\begin{tabular}{lllll}
\hline \multicolumn{4}{l}{ Time $(\min )$} & 30 \\
\cline { 2 - 5 } & 5 & 15 & 30 & 60 \\
\hline $\mathrm{DCE}(\mathrm{mM})^{\star}$ & $4.4(0.03)$ & $5.8(0.01)$ & $6.5(0.02)$ & $6.5(0.02)$ \\
\hline
\end{tabular}

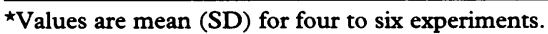

samples were left overnight at $4^{\circ} \mathrm{C}$, and then the precipitates were reharvested after centrifugation at $10000 \mathrm{~g}$ for 45 minutes. ${ }^{24}$

\section{DETERMINATION OF LIPID AND SUGAR BOUND} SPECIFIC RADIOACTIVITY

To evaluate the incorporation of ${ }^{3} \mathrm{H}-\mathrm{Na}-$ palmitate and ${ }^{14} \mathrm{C}$-glucosamine into the subcellular fractions and the concentrations in the lipoglycoproteins secreted into suspension medium $C$, the aliquots were processed as follows: Samples of cell homogenate, cytosol, total microsomes, and Golgi apparatus to be counted were processed by addition of cold $\left(4^{\circ} \mathrm{C}\right) 1 \%$ phosphotungstic acid in $20 \%$ trichloroacetic acid. The precipitates were washed twice with $5 \%$ trichloroacetic acid and once with distilled water. Aliquots of the trichloroacetic acid washed precipitates were washed three times in $2: 1$ by volume chloroform-methanol mixture, and the protein residue, after lipid extraction, was dissolved in Insta-Gel (Packard). Specific radioactivity was determined with a Packard TriCarb liquid scintillation counter (model 4430), and expressed as $\mathrm{dpm} / 10^{6}$ cells.

Table 2 Effects of exposure to DCE on cell viability, lactate dehydrogenase leakage, and reduced glutathione content of isolated rat hepatocytes

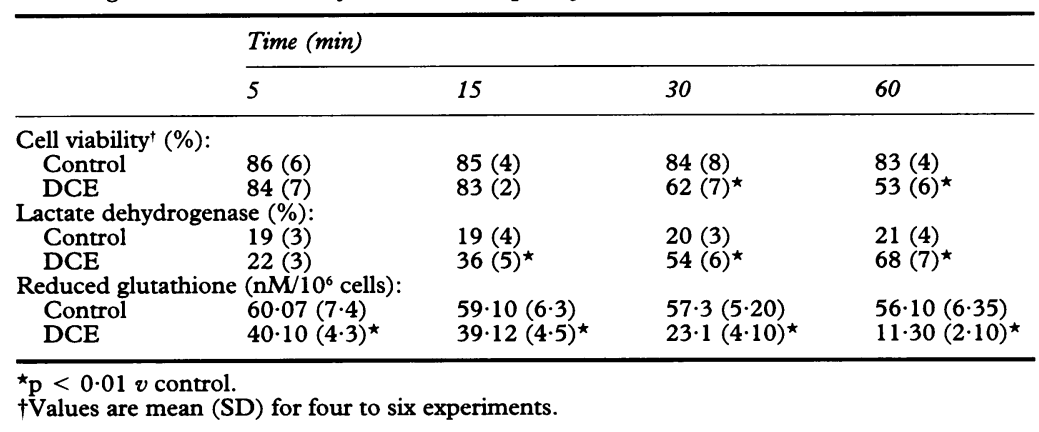

Table 3 Distribution of ${ }^{3} \mathrm{H}-\mathrm{Na}$-palmitate $\left(\mathrm{dpm} / 10^{6} \text { cells) }\right)^{+}$in homogenate and fractions of control and DCE treated hepatocytes

\begin{tabular}{|c|c|c|c|c|}
\hline & \multicolumn{4}{|l|}{ Time (min) } \\
\hline & 5 & 15 & 30 & 60 \\
\hline \multicolumn{5}{|c|}{ Homogenate: } \\
\hline $\begin{array}{l}\text { Control } \\
\text { DCE }\end{array}$ & $\begin{array}{l}245450\left(\begin{array}{ll}26 & 350\end{array}\right) \\
249328\left(\begin{array}{ll}29 & 340\end{array}\right)\end{array}$ & $\begin{array}{l}245320\left(\begin{array}{lll}27 & 200\end{array}\right) \\
257698\left(\begin{array}{ll}31 & 210\end{array}\right)\end{array}$ & $\begin{array}{l}245350\left(\begin{array}{lll}30 & 140\end{array}\right) \\
270 \quad 431\left(\begin{array}{lll}33 & 240\end{array}\right)\end{array}$ & 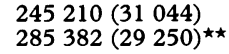 \\
\hline \multicolumn{5}{|c|}{ ex } \\
\hline $\begin{array}{l}\text { Control } \\
\text { DCE }\end{array}$ & $\begin{array}{l}85500(10700) \\
86340(6310)\end{array}$ & 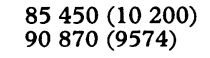 & 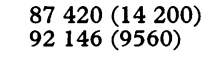 & $\begin{array}{l}86420\left(\begin{array}{lll}12 & 210\end{array}\right) \\
98203\left(\begin{array}{lll}10 & 320)^{\star \star}\end{array}\right.\end{array}$ \\
\hline \multicolumn{5}{|c|}{ Total microsomes: } \\
\hline $\begin{array}{l}\text { Control } \\
\text { DCE }\end{array}$ & $\begin{array}{l}71500(9620) \\
76135(695)\end{array}$ & $\begin{array}{l}71300(9400) \\
85470(7190)^{\star \star}\end{array}$ & 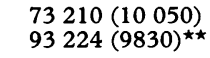 & 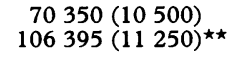 \\
\hline \multicolumn{5}{|c|}{ Total Golgi apparatus: } \\
\hline $\begin{array}{l}\text { Control } \\
\text { DCE }\end{array}$ & $\begin{array}{l}3920(420) \\
5103(223)^{\star \star}\end{array}$ & $\begin{array}{l}3840(340) \\
5404(443) \star \star\end{array}$ & $\begin{array}{l}3721(410) \\
5649(507)^{\star \star}\end{array}$ & $\begin{array}{l}3721(310) \\
6403(851)^{\star \star}\end{array}$ \\
\hline \multicolumn{5}{|c|}{ Secreted lipoglycoproteins: } \\
\hline Control & $1060(128)$ & $2110(275)$ & $3280(358)$ & $4220(518)$ \\
\hline DCE & $480(57)^{\star \star}$ & $910(115)^{\star \star}$ & $1150(135)^{\star \star}$ & $1610(186)^{\star \star}$ \\
\hline
\end{tabular}

$\star \star \mathrm{p}<0.01 v$ control.

$\dagger$ Values are mean (SD) for four to six experiments; cells were incubated for 5-60 minutes with the label.
STATISTICAL EVALUATION

All experiments were measured at least in triplicate. The results are expressed as the means (SD) of four to six different preparations of isolated rat hepatocytes. To compare the relation between the ${ }^{3} \mathrm{H}-\mathrm{Na}$-palmitate and ${ }^{14} \mathrm{C}$-glucosamine bound specific radioactivity secreted into suspension medium $\mathrm{C}$ and the time of incubation, we performed linear regression analysis with the method of least squares, and then calculated the correlation coefficient $(r)$. The differences were determined by Student-Fisher's $t$ test, and were considered significant when $t$ values corresponded to $\mathrm{p}<0.01$.

\section{Results}

Table 1 shows that the actual concentration of DCE ( $\mathrm{mM})$ in the cell suspension medium increased from $4.4(0.03)$ to $6.5(0.02) \mathrm{mM}$, reaching a plateau after 30 minutes.

Table 2 shows hepatocyte viability, evaluated by the trypan blue exclusion test, lactate dehydrogenase leakage, and intracellular reduced glutathione content after different times of incubation (from five to 60 minutes). Cell preparations with viability ranging from $83 \%$ to $86 \%$ were used. In agreement with several authors, ${ }^{25}$ a $15 \%-18 \%$ range of damaged cells did not significantly interfere with reproducibility of experimental data. In untreated hepatocytes, both cell viability and reduced glutathione content remained unchanged for 60 minutes, confirming that cell integrity did not change after the isolation procedures. After five minutes of exposure, DCE did not induce obvious changes in cell viability and lactate dehydrogenase leakage. Thereafter, these data showed significant changes $(p<0.01)$, pronounced after 60 minutes of incubation $(53 \%(6 \%)$ for cell viability and $68 \%(7 \%)$ for leakage of lactate dehydrogenase compared with control values).

Changes in the concentration of reduced glutathione in hepatocytes were already found at five minutes $\left(40 \cdot 10(4 \cdot 3) \mathrm{nM} / 10^{6}\right.$ cells). Successively, the depletion of reduced glutathione increased abruptly, in particular after 60 minutes of incubation $(11.30(2 \cdot 10)$ $\mathrm{nM} / 10^{6}$ cells).

Tables 3 and 4 show the time course of incorporation of ${ }^{3} \mathrm{H}-\mathrm{Na}$-palmitate and ${ }^{14} \mathrm{C}$ glucosamine into subcellular fractions and secreted lipoglycoproteins. In cells poisoned by DCE there was a large decrease in secretion of lipoglycoproteins with a concomitant progressive accumulation of prelabelled precursors inside the cells. In total Golgi apparatus and microsomes ${ }^{3} \mathrm{H}-\mathrm{Na}$-palmitate specific radioactivity showed a significant increase $(\mathrm{p}<0.01)$, starting after five minutes (5103 (223) $\mathrm{dpm} / 10^{6}$ cells), and 15 minutes (85 470 (7190) $\mathrm{dpm} / 10^{6}$ cells) reaching a peak at 60 minutes $\left(6403(851) \mathrm{dpm} / 10^{6}\right.$ cells in the Golgi apparatus, and 106395 (11 250) $\mathrm{dpm} / 10^{6}$ cells in the microsomes). At the same time the lipid bound radioactivity was significantly raised $(p<0.01)$ in homogenates 
Table 4 Distribution of ${ }^{14} \mathrm{C}$-glucosamine $\left(\mathrm{dpm} / 10^{6} \text { cells }\right)^{\dagger}$ into homogenate and fractions of control and DCE treated hepatocytes

\begin{tabular}{|c|c|c|c|c|}
\hline & \multicolumn{4}{|l|}{ Time (min) } \\
\hline & 5 & 15 & 30 & 60 \\
\hline \multicolumn{5}{|c|}{ Homogenate: } \\
\hline $\begin{array}{l}\text { Control } \\
\text { DCE }\end{array}$ & $\begin{array}{l}75430(5800) \\
77840(7120)\end{array}$ & $\begin{array}{l}75210(6250) \\
80842(8570)\end{array}$ & $\begin{array}{l}74250(7210) \\
84938(9740)\end{array}$ & $\begin{array}{l}76320(7410) \\
87812(10720)^{\star}\end{array}$ \\
\hline \multicolumn{5}{|l|}{$\begin{array}{l}\text { Cytosol: } \\
\text { Cyto }\end{array}$} \\
\hline $\begin{array}{l}\text { Control } \\
\text { DCE }\end{array}$ & $\begin{array}{l}37420(3121) \\
39510(3570)\end{array}$ & $\begin{array}{l}40500(5600) \\
42771(5210)\end{array}$ & $\begin{array}{l}42324(6050) \\
44615(5730)\end{array}$ & $\begin{array}{l}41340(5700) \\
46245(6270)\end{array}$ \\
\hline \multicolumn{5}{|c|}{ Total microsomes: } \\
\hline $\begin{array}{l}\text { Control } \\
\text { DCE }\end{array}$ & $\begin{array}{l}13131(1350) \\
14435(1430)\end{array}$ & $\begin{array}{l}14320(2200) \\
15975(2035)^{\star}\end{array}$ & $\begin{array}{l}15030(1970) \\
18846(1970)^{\star}\end{array}$ & $\begin{array}{l}14900(2030) \\
20060(2275)^{\star}\end{array}$ \\
\hline \multicolumn{5}{|c|}{ Total Golgi apparatus: } \\
\hline $\begin{array}{l}\text { Control } \\
\text { DCE }\end{array}$ & $\begin{array}{l}551(42) \\
690(55)^{\star}\end{array}$ & $\begin{array}{l}685(75) \\
810(60)^{\star}\end{array}$ & $\begin{array}{l}720(85) \\
965(115)^{\star}\end{array}$ & $\begin{array}{c}750(80) \\
1082(125)^{\star}\end{array}$ \\
\hline \multicolumn{5}{|c|}{ Secreted lipoglycoproteins: } \\
\hline $\begin{array}{l}\text { Control } \\
\text { DCE }\end{array}$ & $\begin{array}{l}650(73) \\
315(45)^{\star}\end{array}$ & $\begin{array}{r}1380(157) \\
560(69)^{\star}\end{array}$ & $\begin{array}{l}2100(256) \\
980(118)^{\star}\end{array}$ & $\begin{array}{l}2980(365) \\
1530(179)^{\star}\end{array}$ \\
\hline
\end{tabular}

${ }^{\star} \mathrm{p}<0.01 v$ control

+Values are mean (SD) for four to six experiments; cells were incubated for 5-60 minutes with the label.

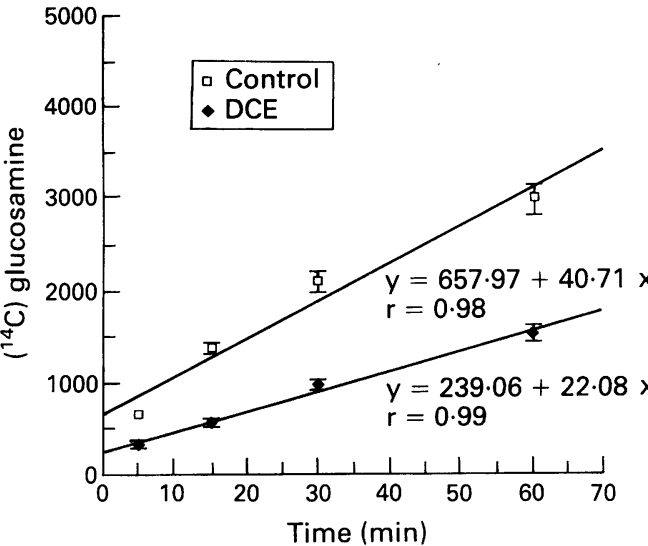

Figure 2 Relation between the lipoglycoprotein bound radioactivity of the ${ }^{14} \mathrm{C}$-glucosamine secreted into the medium and the time of incubation in control and DCE treated cells.

(285 $382(29250) \mathrm{dpm} / 10^{6}$ cells) and cytosol (98 203 (10 320) dpm/106 cells). Moreover, we found a significant increase $(p<0.01)$ of ${ }^{14} \mathrm{C}$-glucosamine content in total Golgi apparatus (690 (55) dpm $/ 10^{6}$ cells) and microsomes $\left(15975(2035) \mathrm{dpm} / 10^{6}\right.$ cells) at five and 15 minutes (table 4). Thereafter, the sugar bound radioactivity in these subcellular fractions steadily increased, reaching a peak 60 minutes after exposure to DCE. Tables 3 and 4 report experiments in which the specific radioactivity of lipid and sugar moieties incorporated into secreted lipoglycoproteins was determined. Interestingly, as early as five minutes after poisoning, when DCE does not induce obvious changes in cell viability, we already found a significant block of secretion of both ${ }^{3} \mathrm{H}$-Na-palmitate and ${ }^{14} \mathrm{C}$-glucosamine in the medium $\left(480\right.$ (57) $\mathrm{dpm} / 10^{6}$ cells for palmitate, and 315 (45) $\mathrm{dpm} / 10^{6}$ cells for glucosomine). To confirm these results, the slope of the straight line relating lipoglycoprotein bound radioactivity to the time of incubation was calculated (figs 1 and 2 ). The decreased slope of the straight lines in DCE exposed $v$ untreated cells shows a significant block of lipoglycoprotein secretion $(p<0.01)$ as early as five minutes after exposure.

\section{Discussion}

Studies from different laboratories have stressed that the use of intact hepatocytes

Figure 1 Relation between the lipoglycoprotein bound radioactivity of ${ }^{3} \mathrm{H}-\mathrm{Na}$ palmitate secreted into the medium and the time of incubation in control and DCE treated cells.

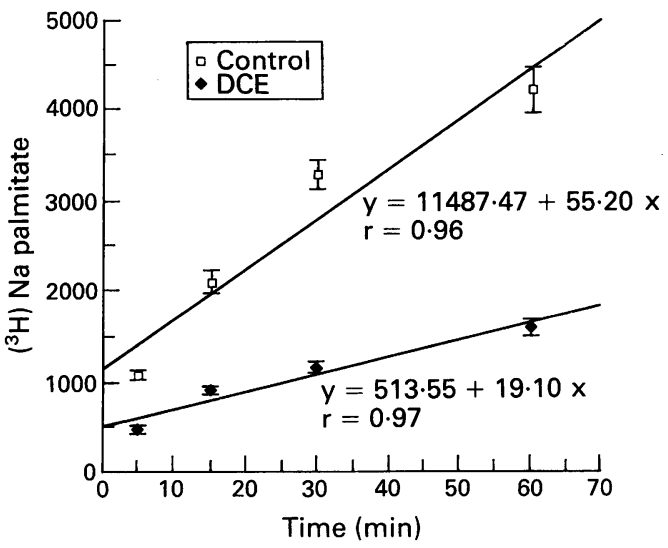

represents a useful integration of experimental systems for in vitro studies about the derangement of secretion of lipoglycoproteins and the pro-oxidant effects of several drugs and xenobiotics. ${ }^{27-29}$

Our results have shown that hepatocytes, in single cell suspensions, can mimic in part the whole liver with regard to some responses to $\mathrm{DCE}$ poisoning. In isolated hepatocytes ${ }^{10}$ and in vivo, ${ }^{5}$ DCE induces an early fat accumulation within the cells, probably through an impairment of the secretion of lipoglycoproteins. When DCE is added to the suspension of hepatocytes there is not only a dramatic decrease in cell trypan blue exclusion, but also a leakage of lactate dehydrogenase. Moreover, in hepatocytes poisoned with this xenobiotic compound there was a striking depletion of intracellular reduced glutathione content, already significant after only five minutes of exposure. Hence, as the reduced glutathione may function as a substrate for the quenching of reactive oxygen species, ${ }^{3031}$ these findings support the hypothesis that depletion of reduced glutathione can play a crucial part in the pathogenesis of liver injuries induced by DCE. In this study, isolated hepatocytes prelabelled with ${ }^{3} \mathrm{H}-\mathrm{Na}$-palmitate and ${ }^{14} \mathrm{C}$ glucosamine at the level of the lipoglycoprotein fraction, showed a significant block of secretion of lipoglycoprotein as early as five minutes after DCE poisoning. Identical experiments of cell prelabelling, looking this time also at the total lipid and sugar content of the Golgi apparatus not only confirmed the secretory block but also showed evidence of an increase of labelled material into the total Golgi apparatus of the poisoned cells with respect to the untreated ones, early after exposure to DCE. In fact, at 15 minutes the secretion of ${ }^{3} \mathrm{H}-\mathrm{Na}$-palmitate was reduced by $57 \%$ and ${ }^{14} \mathrm{C}$-glucosamine was reduced by $60 \%$ compared with controls. At the same time, the percentage increase of intracellular lipid and sugar bound radioactivity was already significant with respect to controls in total Golgi apparatus and microsomes but not in cytosol. These findings suggest that lipid retention at the sites of processing of lipoglycoprotein would play a key part in 
the early stages of cell fat storage after exposure to DCE.

Tables 3 and 4 show the time course of incorporation of prelabelled lipid and sugar precursors in intracellular and secreted lipoglycoproteins. In cells treated with DCE there is a striking impairment of secretion of lipoglycoproteins with a concomitant, progressive accumulation of ${ }^{3} \mathrm{H}-\mathrm{Na}$-palmitate and ${ }^{14} \mathrm{C}$ glucosamine inside the cells. These results indicate that DCE produces liver cell steatosis in vitro. Furthermore, there is a good quantitative relation between the increased intracellular radioactivity, and the decrease in secretion of prelabelled precursors: These experimental findings are in agreement with the results of previously reported studies concerning poisoning with $\mathrm{CCl}_{4}$. In fact, Poli et al, have pointed out that this haloalkane, as early as five minutes after exposure, is able to impair the secretory subfraction (F1) of the Golgi apparatus purified from total microsomes, and at 15 minutes both to impair the intermediate (F2) and the formative (F3) sides of the apparatus, which play a pivotal part in the secretion of lipoglycoproteins outside the cell. ${ }^{32}$

In summary, our results indicate an impairment of Golgi apparatus in the liver during early phases of acute poisoning with DCE. Hence, even if our results do not exclude a favouring, indirect part played by a possible increase of uptake of fatty acid by hepatocytes treated with DCE in the pathogenesis of toxic fatty liver, the direct damage of such cells leading to an early block of secretion of lipoglycoproteins seems to be of paramount importance.

This work was supported in part by a grant from National Research Council (CNR) targeted project "Prevention and control of disease factors", subproject "SP2 9200143 PF 41, Rome, Italy, and by a grant from ACNA CO, Cengio (Sv), Italy.

1 International Agency for Research on Cancer Expert Committee. Monographs on the evaluation of the carcinogenic risk of chemical to humans, vol 20). Some halogenated hydrocarbons, 1,2-Dichloroethane. Lyons: IARC, 1979.

2 Gold LS. Human exposures to ethylene dichloride. In: Ames B, Infante P, Reitz R, eds. Ethylene dichloride: $a$ potential health risk? Cold Spring Harbor: Cold Spring Harbor Laboratory, 1980:209-25. (Banbury Report No 5.)

3 Hadengue MA, Martin R. Un cas d'intoxication mortelle par le dichloroéthane. Annales de Médecine Légale et de priminologie 1953;33:247-9.

4 Paparopoli G, Cali V. Collective intoxications with chlorinated hydrocarbons in dock workers. Folia Med 1956; 39:819-31.

5 Fontana L, Barisione G, Cottalasso D, Domenicotti C, Pronzato MA. Effetti sperimentali e clinici dell'intossicazione da 1,2-dicloroetano. Arch Scienze Lav 1989;5: 123-31.

6 Spencer HC, Rowe VK, Adams EM, McCollister DD, Irish DD. Vapor toxicity of ethylene dichloride determined by experiments on laboratory animals. Arch Ind Hyg Occup Med 1951;4:482-93.

7 Guengerich FP, Crawford WM, Domoradzki JY, MacDonald TL, Watanabe PG. In vitro activation of 1,2-dichloroethane by microsomal and cytosolic 1,2-dichloroethane by microsomal and cyt

8 Rannug U, Sundvall A, Ramel C. The mutagenic effect of 1,2-dichloroethane on Salmonella typhimurium. I. Activation through conjunction with glutathione in Activation through conjunction with
vitro. Chem Biol Interact 1978;20:1-16.
9 Cottalasso D, Pronzato MA, Domenicotti C, Baccelliere L, Fontana L, Barisione G. Indagine sperimentale sul metabolismo epatico del 1,2-dicloroetano. Lavoro $e$ Medicina 1989;3:5-10.

10 Cottalasso D, Pronzato MA, Domenicotti C, Barisione G, Fontana L. Tossicità dell' 1,2-dicloroetano e del 3,4dicloronitrobenzene su epatociti isolati di ratto. Effetti del Trolox e della prometazina, e comportamento del GSH. Arch Scienze Lav 1989;5:133-8.

11 Slater TF, ed. Free radical mechanisms in tissue injury. London: Pion Ltd, 1972.

12 Dianzani MU. Biochemical aspects of fatty liver. In: Slater TF, ed. Biochemical mechanism of liver injury. London: Academic Press, 1978:45-95.

13 Brattin WJ, Glende EA Jr, Recknagel RO. Pathological mechanism in carbon tetrachloride hepatotoxicity. $\mathcal{F}$ Free Rad Biol Med 1985;1:27-38.

14 Nanni G, Cottalasso D, Cetta G, Pronzato MA, Marinari UM. Ethanol-induced impairment of glycoprotein metabolism in liver Golgi apparatus. In: Rosen P, ed. Frontiers of Gastrointestinal Research. Basel: Karger, Frontiers of $1986 ; 9: 50-69$.

15 Poli G, Gravela E, Albano E, Dianzani MU. Studies on fatty liver with isolated hepatocytes. II. The action of carbon tetrachloride on lipid peroxidation, protein, and triglyceride synthesis and secretion. Exp Mol Pathol 1979;30:116-27.

16 Poli G, Chiarpotto E, Albano E, et al. Carbon tetrachloride-induced inhibition of hepatocyte lipoprotein secretion: functional impairment of Golgi apparatus in the early phases of such injury. Life Sci 1985;36:533-9.

17 Pronzato MA, Cottalasso D, Domenicotti C, et al. Effects of $\mathrm{CCl}_{4}$ poisoning on metabolism of dolichol in rat liver microsomes and Golgi apparatus. Free Radic Res microsomes and Golgi

18 Cottalasso D, Pronzato MA, Domenicotti C, Nanni G, Marinari MU. Ethanol-induced decrease of dolichol levels in the rat liver microsomes and Golgi apparatus. In: Dianzani MU, Gentilini P, eds. Chronic liver damage. Amsterdam: Elsevier, 1990:39-50.

19 Berry MN, Friend DS. High-yield preparation of isolated liver parenchimal cells. $\mathcal{F}$ Cell Biol 1969;43:506-20.

20 Jeejeebhoy KN, Ho J, Greenberg GR, Phillips MJ, BruceRobertson A, Sodtke U. Albumin, fibrinogen, and transferrin synthesis in isolated rat hepatocyte suspensions. Biochem $\mathcal{F} 1975 ; 146: 141-55$.

21 Albano E, Poli G, Tomasi A, Bini A, Vannini V, Dianzani MU. Toxicity of 1,2-dibromoethane in isolated hepatoMU. Toxicity of 1,2-dibromoethane in isolated hepatocytes: role of lipid

22 Poli G, Dianzani MU, Cheeseman KH, Slater TF, Lang $J$, Esterbauer $H$. Separation and characterization of the aldehydic products of lipid peroxidation stimulated by carbon tetrachloride or ADP-iron in isolated rat hepatocytes and rat liver microsomal suspension. Biochem $\mathcal{f}$ 1985;227:629-38.

23 Shedlofsky SI, Sinclair PF, Sinclair JF, Bonkovski HL. Increased glutathione in cultured hepatocytes associated with induction of cytochrome P-450. Lack of effect of glutathione depletion on induction of cytochrome P-450 and $\delta$-aminolevulinate synthetase. Biochem Pharmacol and $\delta$-aminolevulinate

24 Poli G, Albano E, Biasi F, Chiarpotto E, Dianzani MU. In vitro evidence for $\mathrm{CCl}_{4}$ metabolites covalently bound to lipoprotein micelles. FEBS Lett 1983;160:187-94.

25 Chiarpotto E, Olivero J, Albano E, Poli G, Gravela E, Dianzani MU. Studies on lipid peroxidation using whole liver cells: influence of damaged cells on the prooxidant effect of ADP-Fe ${ }^{3+}$ and $\mathrm{CC}_{14}$. Experientia 1981;37:396-7.

26 Chiarpotto E, Poli G, Albano E, Gravela E, Dianzani MU. Studies on fatty liver with isolated hepatocytes. III. Cumene hydroperoxide-induced change of several cell functions. Exp Mol Pathol 1984;41:191-201.

27 Dianzani MU, Poli G, Gravela E, Chiarpotto E, Albano E. Influence of lipid peroxidation on lipoprotein secreE. Influence of lipid peroxidation on lipoprotein

28 Biasi $\mathrm{F}$, Albano $\mathrm{E}$, Chiarpotto $\mathrm{E}$, et al. In vivo and in vitro evidence concerning the role of lipid peroxidation in the mechanism of hepatocyte death due to carbon tetrachloride. Cell Biochem Funct 1991;9:111-8.

29 Poli G, Chiarpotto E, Albano E, et al. Biochemical evidence for chemical and/or topographic differences in the lipoperoxidative processes induced by $\mathrm{CCl}_{4}$ and iron. Chem Biol Interact 1983;43:253-61.

30 Haenen GRMM, Vermeulen NPE, Timmerman H, Bast A. Effect of thiols on lipid peroxidation in rat liver microsomes. Chem Biol Interact 1989;71:201-12.

31 Wefers $H$, Sies $H$. The protection by ascorbate and glutathione against microsomal lipid peroxidation is depentathione against microsomal lipid peroxidation is depe

32 Poli G, Cottalasso D, Pronzato MA, et al. Lipid peroxidation and covalent binding in the early functional impairtion and covalent binding in the early functional impair-
ment of liver Golgi apparatus by carbon tetrachloride. Cell Biochem Funct 1990;8:1-10. 